\title{
COMMUNICATIVE FUNCTIONS AND THE MEANINGS OF SLOGANS IN PUBLIC SERVICE ADVERTISEMENTS
}

\author{
Sastika Seli, Tari Damayanti, Dewi Syafitri \\ selisastika@gmail.com, taridada33@gmail.com, dewisyafitristkipllg@gmail.com \\ English Education Program, FKIP, STKIP PGRI Lubuklinggau
}

\begin{abstract}
This research aims at describing the communicative functions and the meaning of Slogans in Public Service Advertisements (PSA). This is a descriptive-qualitative research. The data derived from 20 PSA videos downloaded from Youtube. Then, they are collected through document analysis and analyzed with content analysis. There are only four types of meaning stated by Leech (1985) e.i 12 slogans with conceptual meanings, 7 slogans with connotative meanings, 7 slogans with affective meanings and 1 slogan with social meanings. Based on the Illocutionary acts, some communicative functions found in PSA slogans are 1) to invite society to do something, 2) to inform people, 3) to report or to state something important, 4) to express emotion, and 5) to convince people doing something in the future.
\end{abstract}

Keywords: PSA slogans, communicative functions, language meaning, illocutionary act, speech act

\section{INTRODUCTION}

In communication, people will use different ways in speaking directly by using media such as through telephone, letter, internet, slogan, poems, song lyrics, etc. They can be everywhere and anywhere in people's life. People will be easier to catch the meaning or intention of something from those media.

A slogan is any form of business branding plan which involves the creation (Rueb, 2016:5). It is one of the basic elements necessary in building an effective brand campaign. A slogan typically consists of a short sentence or a phrase that serve to reinforce the business name or logo. They are frequently used with a main trade mark or house mark to create a positive sentiment, aura or cachet to be associated with that brand of goods or services. Slogan is found in different kinds of advertisements. It is made uniquely and creatively because the function is to attract people. Commercial organizations spend a lot of effort and money on naming products, devising slogans, and creating messages that will be meaningful to the buying public 
(Kreidler, 1998:2). Advertisement slogans are commercial tools to promote something. Therefore, the language has to be simple, attractive and economic (Noor, Mustafa, Muhabat \&Kazemian, 2015:8).

The example of slogan is baby it's Maybelline. It is one of slogan used in one of cosmetic advertisement by one of lipstick product from America. The slogan means a clear confirmation to show a good lipstick for woman stated by the word baby. Address term baby means an intimate term to call someone with close relationship. This advertisement strategy is to make the audience who see feel closer to the product and wish to buy.

This advertisement has a purpose on issues that impact society on a larger scale, such as family planning, national integration, polio eradication, pollution control, smoking, alcohol, safety, other health diseases (Manickavelan, n.d.). In addition, Public service advertising is using the techniques of commercial advertising for non-commercial purposes (Suresh \&
Srinivasan, 2008:1). It is mainly used as a tool to promote social welfare.

One of the examples of slogan in English public service advertisement is "Don't drink and drive". It is found in advertisement about car accident where many people die in USA because people were drunk while driving cars or motorcycles. It causes many accidents that cause the death of humans. This advertisement asks people to be more aware to self safety and others' safety.

From the example above, it is known that in creating the slogans the advertisement makers must consider some points. It can be the consideration of the meaning that has purpose to attract audience. When people see that the purpose of PSA is to communicate with society, probably they think the meaning must be social. However, there are seven types of meaning stated by Leech (1985:12). Therefore, it is not completely correct to think about one meaning. PSA may have 
different meaning in the form of its expression.

Furthermore, PSA as kinds of expression used to communicate with society may have different purposes. They may function to educate, alert, influence, and invite the society as audience (Paul, 2011; Siuyi, 2006) through words, images, and symbols, (Farwell, 2012). Therefore, PSA must be communicative. Any utterances or sentences with communicative purpose are part of illocutionary act (Yule, 2006). It is important to describe the speech acts of the slogans in order to know what they are trying to accomplish. Thus, the messages will be delivered easily to the targeted society.

\section{RESEARCH METHOD}

The study was a descriptive study. Descriptive study involves gathering data that describe events and then organizes, tabulates, depicts, and describes the data collection (Glass \& Hopkins, 1984:285).

Descriptive study can be either quantitative or qualitative. The study was a qualitative descriptive because it contains nonnumerical data which be explained in sentences and the analysis will not through statistical procedure.

The primary data is the data which is being observed. In this study, the primary or main data came from verbal (oral and written) language used in public service advertisement. The data were English slogan in public service advertisement videos. If the primary data came from public service advertisement videos, the secondary data came from articles, books and other literatures. The data supported the primary data.

The data were collected through document analysis. Then, they were analyzed with content analysis by identifying, classifying, reducing, describing and drawing conclusion. 


\section{FINDINGS AND DISCUSSION}

This section presents the results

and the discussion of the research. The first

finding is the types of PSA slogans

meaning and the second is the types of

communicative function of PSA slogans in

illocutionary acts.

Findings
The meaning of PSA Slogans

According to Leech (1985:9),

there are seven types of the language meaning, namely, conceptual meaning, connotative meaning, social meaning, affective meaning, reflected meaning, collocative meaning, and thematic meaning.

Table 1. Types of Meaning Found in English PSA Videos

\begin{tabular}{|c|c|c|c|}
\hline Slogans & Forms of Ad & Types of meaning & Meaning \\
\hline $\begin{array}{l}\text { Your everyday gestures can } \\
\text { help them heal }\end{array}$ & Children & Conceptual & $\begin{array}{l}\text { Gestures means the body movement that } \\
\text { used to communicate, supporting gesture } \\
\text { like hug, shake hand, touching can help } \\
\text { children as victim of the trauma. }\end{array}$ \\
\hline $\begin{array}{l}\text { Online predators know how } \\
\text { they're doing, do you? }\end{array}$ & Children & Connotative & $\begin{array}{l}\text { Online predators mean criminal who find } \\
\text { the victims from the internet like social } \\
\text { media. Most of victims are children and } \\
\text { teenagers. So people have to watch their } \\
\text { children, families and relatives to stay } \\
\text { away from them. }\end{array}$ \\
\hline I'm a witness, so are you & Children & Conceptual, Affective & $\begin{array}{l}\text { Witness is a person who sees a crime. } \\
\text { There are children who see a crime and it } \\
\text { cause trauma. This crime is bullying at } \\
\text { school. }\end{array}$ \\
\hline For every child in danger & Children & Conceptual & $\begin{array}{l}\text { This slogan mean to protect every child } \\
\text { from crimes because anybody can do bad } \\
\text { things to them }\end{array}$ \\
\hline $\begin{array}{l}\text { A message only for children, } \\
\text { and the warn for adults }\end{array}$ & Children & Conceptual & $\begin{array}{l}\text { There is a line to phone for children who } \\
\text { are in danger because of physical crime. }\end{array}$ \\
\hline There still time & Environment & Conceptual, Affective & $\begin{array}{l}\text { People still have many times to change to } \\
\text { safe environment that will not harm our } \\
\text { children }\end{array}$ \\
\hline It helped us, make it up PA! & Environment & Conceptual, Social & $\begin{array}{l}\text { The activities supported by PA or } \\
\text { Pennsylvania is very useful to make clean } \\
\text { environment }\end{array}$ \\
\hline Is this the future we want for it? & Environment & Conceptual & $\begin{array}{l}\text { Tell people to stop destroying earth and } \\
\text { protect it together }\end{array}$ \\
\hline $\begin{array}{l}\text { You can make a difference. } \\
\text { Don't support animal testing }\end{array}$ & Environment & Conceptual & $\begin{array}{l}\text { Make a difference means do something } \\
\text { that people do not by stopping and } \\
\text { supporting against animal testing to make } \\
\text { cosmetics }\end{array}$ \\
\hline $\begin{array}{l}\text { Change your future at } \\
\text { makehealthlast.ca }\end{array}$ & Health & Conceptual & $\begin{array}{l}\text { There is a foundation in makehealthlast.ca } \\
\text { that support people to live healthy }\end{array}$ \\
\hline Good start, great finish & Health & Connotative & $\begin{array}{l}\text { Good start means start to have healthy life } \\
\text { style so we will live longer in the future }\end{array}$ \\
\hline
\end{tabular}


p-ISSN: 2085-1383; e-ISSN: 2621-4156

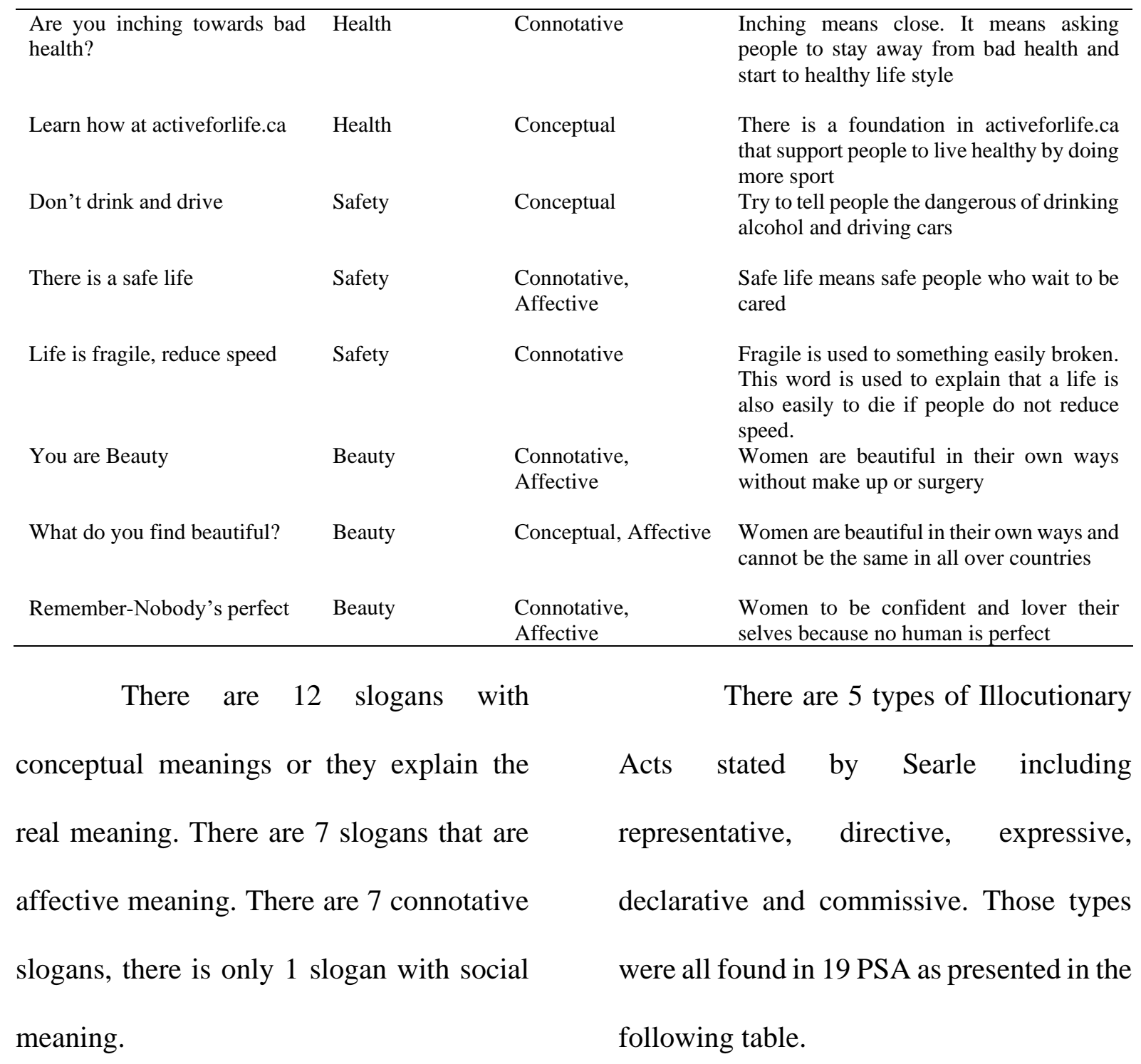

Types of Illocutionary Acts in PSA

Table 2. Communicative Functions of PSA Slogans

\begin{tabular}{|c|c|c|c|c|c|}
\hline PSA Slogans & \multicolumn{5}{|c|}{ Communicative Functions of PSA Slogans } \\
\hline $\begin{array}{l}\text { Your everyday gestures can help } \\
\text { them heal }\end{array}$ & representative & $\begin{array}{r}\text { Directive } \\
\sqrt{ }\end{array}$ & Expressive & Declarative & Commissive \\
\hline $\begin{array}{l}\text { Online predators know how } \\
\text { they're doing, do you? }\end{array}$ & & & $\sqrt{ }$ & & \\
\hline
\end{tabular}


I'm a witness, so are you

For every child in danger $\quad \sqrt{ }$

A message only for children, and $\sqrt{ }$

the warn for adults

There still time

It helped us, make it up PA!

You can make a difference. Don't

support animal testing

Change your future at

makehealthlast.ca

Good start, great finish

$\sqrt{ }$

Learn how at activeforlife.ca

$\sqrt{2}$

Don't drink and drive

There is a safe life

$\sqrt{ }$

Life is fragile, reduce speed

$\sqrt{ }$

You are Beauty

Remember-Nobody's perfect

Together we are beating Covid-

19, keep up the fight!

There are 4 slogans with representative act, 7 slogans with directive act, 3 slogans with declarative act, 1 slogan with expressive act and 2 slogan with commissive act.

\section{Discussion}

The Meanings of PSA Slogans

In the analysis of meaning from 7 types of meaning by Leech, there are only four types meaning found in PSA slogans such as conceptual, connotative, affective and social. In this part, it will be explained 
in detail description of those four meanings in PSA slogans.

The first type of meaning is conceptual meaning. Conceptual meaning also called as denotative or cognitive meaning. It covers essential components of meaning that are conveyed by the literal use of a word (Yule, 2010:113). People say it as the real meaning without any second meaning.

From the data, conceptual meaning appears such as in the following slogans:

a. Your everyday gestures can help them heal

b. For every child in danger

c. Is this the future we want for it?

Those three sentences do not need a deeper understanding. For sentence a Your everyday gestures can help them heal explain about the gestures which mean the move of people body that can help them (children) heal (cure) their bad experience from childhood trauma. Childhood trauma comes from sexual abuse, physical abuse and psychological crime that they receive from families or nearest people. This slogan is to campaign the social treatment that ask people to care about children in their society.

The connotative meanings were the communicative value an expression has by virtue of what it refers to, over and above its purely conceptual content (Leech, 1985:12). It means the meaning can be something else according to the conceptual content. If we read the sentence or words, it can have another meaning with the meaning that we know. So the meaning can be stand for another meaning according to the context.

The slogan with connotative meaning can be identified from the several examples, such as:

a. Online predators know how they're doing, do you?

b. Good start, great finish

c. Are you inching towards bad health? 
The slogan in $a$ there is a word predator that means animal who prey for another animal such as lion, tiger, wolf, etc. In the slogan predator is used to refer a criminal who after children through the internet such as social media and email. They can do some bad things from abusing to killing. This slogan asks people to give more attention to children and family members to stay away from online predators.

The example $b$ good start, great finish needs more understanding in interpret the meaning. We do not understand by looking at good start and good finish without looking at other information. Good start here means fine initial activity in trying to get a healthy life style such as eating healthy food and having sport. Good finish means after having fine life style, our body become healthy and we have a longer life without diseases.

Example $c$ Are you inching towards bad health? also slogan of health which means get closer to bad health.
Inching means get closer and so close. It means if we do not exercise people will grow fat and fatter that will cause many diseases. The slogan asks people to prevent obesity caused by junk food and life without exercising. Therefore, bad health must be avoiding through good life habit.

The third is affective meaning relates to consideration of how language reflects the personal feelings of the speaker, including his attitude to the listener or his attitude to something he is talking about (Leech, 1985:15). It means the slogan have to reflect the personal emotion that contain the messages which have to be stated or informed to audience or society.

Slogans with affective meaning are presented in the following sentences:

a. I'm a witness, so are you

b. Remember-Nobody's perfect

c. There is a safe life

Those slogans are stated with emotional feelings and it is known by the context and content in the video. In $a$ I'm $a$ witness, so are you is said by a teenager 
who see a bullying at school to her friend.

The narrator stated this slogan to state and emphasize that everybody can see bullying but they just keep silent. It is emotional enough to say that the victim of bullying needed to be protected.

In a beauty PSA, there is Remember-Nobody's perfect that contain the message about the beauty of women. The word remember is strong stated to emphasize that women must always remember and bless that human is born with beauty. And also to remind that human is not God that nobody is perfect.

In a safety PSA, there slogan there is a safe life which is emotionally stated to audience to remind people for not become busy and must remember the people at home. Safe life means some people or family member that waiting for another member to come home safely that will gather with the family. It is a reminder to people don't get too busy.
The last slogan contains social meaning, namely, It helped us, make it up PA!. The slogan has social meaning because the language conveys about the social circumstances of its use (Leech, 1985: 14). People recognize the words or pronunciation as being dialectal. It can tell someone geographical or social origin. The slogan is characterized by American dialect make it up PA and also showed by PA which is the abbreviation of Pennsylvania.

In conclusion, slogans found in English PSA of four variants were shared in different sentences concerned to declarative, imperative and interrogative simple sentence. Declarative sentence form is as the most sentences that occur in the PSA because it contains information statements. Imperative occurred to give information of instruction, order, asking, desisting and preventing someone to do something. It functions to give a hard push to avoiding something bad and doing a better action for life. Interrogative or 
questions function to convincing and asking for information. It also functioned to influence people by convince them whether their actions were right or wrong.

\section{Communicative Functions of PSA Slogans}

As presented in the table previously, PSA slogans from the collected data cover all acts in Illocutionary. It means PSA slogans may function differently based on the purpose of the advertisement. They may have purposes to present some facts, to change the audience perspective, to influence audience emotionally, to invites or advice doing something/some movements, and to show promises and plans in the future (Searle in Rudiawati \& Fitria, 2018:428-429). The functions are stated in acts of representative, directives, expressive, declaratives and commissive. There are 4 representatives, 7 directives, 1 expressive, 3 declaratives, 2 commissive found based on the data analysis. The most used function is directives found in 7 PSA slogans.
In directives, PSA slogans are trying to invite society to do something such as helping and saving people's life and environment. The slogans ask people to keep the environment clean, save the animals, health maintaining, and reduce accidents. This acts are as the most used in the PSA slogans because the function of PSA slogans is mainly to steer people away from negative behavior (Wahingtonpost.com). As explained previously PSA is using the techniques of commercial advertising for noncommercial purposes (Suresh \& Srinivasan, 2008:1). It is used by non-profit organization that cares about people and environment. Therefore, the message in the slogan contains the act of asking people to do something better for the people and its environment.

In representatives, PSA slogans function as information resource in sharing the facts about the world, people and environment. The message lies in PSA slogans with this function is probably 
because the lack of information or awareness of people. These slogans tell about the fact of safety of people including women and children, as well as tell about the health issues. By looking at this information, people is expected to believe on the reality happen in their environment.

In declaratives, PSA slogans function as something to tell about a person or a group. They contain a statement or a report that emphasize this people are serious about the statement. In 'I am a witness, so are you', this slogan state or declare that this woman is a witness of a crime that can be happened surround us. It can be happened to everybody too.

In commissives, PSA slogans function as something to convince people to do something in the future after they see the

\section{CONCLUSION}

In summary, Slogan in Public service advertisement (PSA) has different meaning in the form of its expression. We ads. In slogans 'There still time' and 'Together we are beating Covid-19, keep up the fight!', the messages contain something to convince people that there are still time to do a better thing and there are time in the future to fight covid-19 together.

Expressive act is the least found in PSA slogans based on the data analysis. As Yule (2006) state that expressive act contains the expression of emotion such as pain, joy, sorrow, pleasure. Only one slogan that express the emotion namely: 'Online predators know how they're doing, do you?' This slogan was stated by a girl who worried and cared so much about other girls at her age who are being preyed by online predators. Her utterance shows the emotion that she was feeling.

need to describe the speech acts in slogan in order to know what the meaning is delivered to the audience. The finding from this research, there are 12 slogans with conceptual meanings, 7 slogans with 
connotative meanings, 7 slogans with

affective meanings and 1 slogan with social meanings. Most of slogan in this research is conceptual meaning which has the real meaning without any second meaning. So, the meaning can be understood by the audience from its denotation. Great advertising must be memorable, state a mission, predictable, effective and long lasting for the audience. Slogan is not just a tagline but it must attract the audience believe of the product so it can give a good feeling to the audience.

\section{REFERENCES}

Farwell, J. P. (2012). Persuasion and power: the art of strategic communication. Washington: Georgetown University Press.

Glass, G. V. \& Hopkins, K. D.. (1984). Statistical methods in education. Michigan: Prentice Hall.

Kreidler, C.W. (1998). Introducing English Semantics. New York: Routledge.

Leech. G.N. (1985). Semantics: The Study of Meaning. Middlesex, England: Penguin books Ltd.

Manickavelan, S. (n.d). A Study on the Effect of Public Service Announcement in Television.
National Monthly Refered Journal of Research in Arts and Education. 2(6),26-36. Retrieved from https://www.abhinavjournal.co m/images/Arts_\&_Education/Ju $\underline{\text { n13/3.pdf }}$

Noor, M, Mustafa, R., Muhabat, F., \& Kazemian. B. (2015). The Language of TV Commercials' Slogans: A Semantics Analysis. http://www.sciencepublishinggr oup.com/j/cls. doi: 10.11648/j.cls.20150101.12

Paul, C. (2011). Strategic communication: Origins, concepts, and current debates. California: ABC-CLIO, LLC.

Rudiawati, R. \& Fitria, V. (2018). Speech act in Indonesias' shampoo advertisement. Project. 1 (4). 427 435.

https://journal.ikipsiliwangi.ac.id/in dex.php/project/article/view/1321

Rueb, G. (2016). Brand Management: What You Need to Know about Branding Your Business. Munich: BookRix

Siuyi, W. W. (2006). Political ideology in Hong Kong's Public Service Announcements. In K. Chan (Ed.), Advertising and Hong Kong Society. 55-76. Hong Kong: The Chinese University Press.

Suresh, K \& Srinivasan, M,I. (2008). Public service advertising: Some issues and campaigns. New Delhi: ICFAI University Press.

The best 10 PSAs all the times. https://www.washingtonpost.com/n ational/the-10-best-psas-of-alltime/2013/09/13/10cb0ebe-1bf2- 
E-Link Journal

Vol. 8 No. 1 (2021)

p-ISSN: 2085-1383; e-ISSN: 2621-4156

11e3-8685-

5021e0c41964_gallery.html
Yule, G. (2006). The Study of Language (Third). New York: Cambridge University Press. 